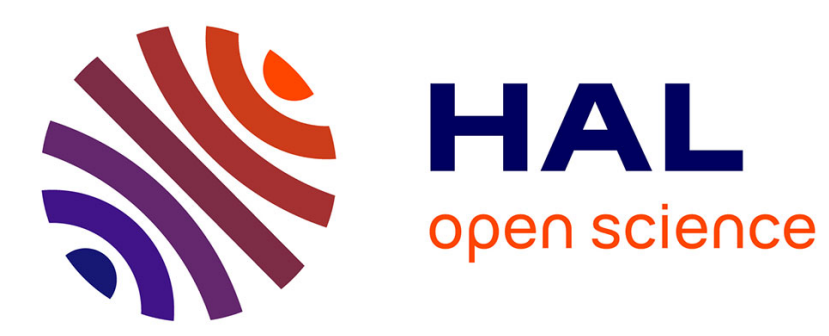

\title{
Sea snakes: overlooked predators at an urban fringing reef \\ Philippe Borsa
}

\section{To cite this version:}

Philippe Borsa. Sea snakes: overlooked predators at an urban fringing reef. Coral Reefs, 2008, 27 (4), pp.743. 10.1007/s00338-008-0437-9 . ird-00369126

\section{HAL Id: ird-00369126 \\ https://hal.ird.fr/ird-00369126}

Submitted on 18 Mar 2009

HAL is a multi-disciplinary open access archive for the deposit and dissemination of scientific research documents, whether they are published or not. The documents may come from teaching and research institutions in France or abroad, or from public or private research centers.
L'archive ouverte pluridisciplinaire HAL, est destinée au dépôt et à la diffusion de documents scientifiques de niveau recherche, publiés ou non, émanant des établissements d'enseignement et de recherche français ou étrangers, des laboratoires publics ou privés. 


\section{Sea snakes: overlooked predators at a urban fringing reef}

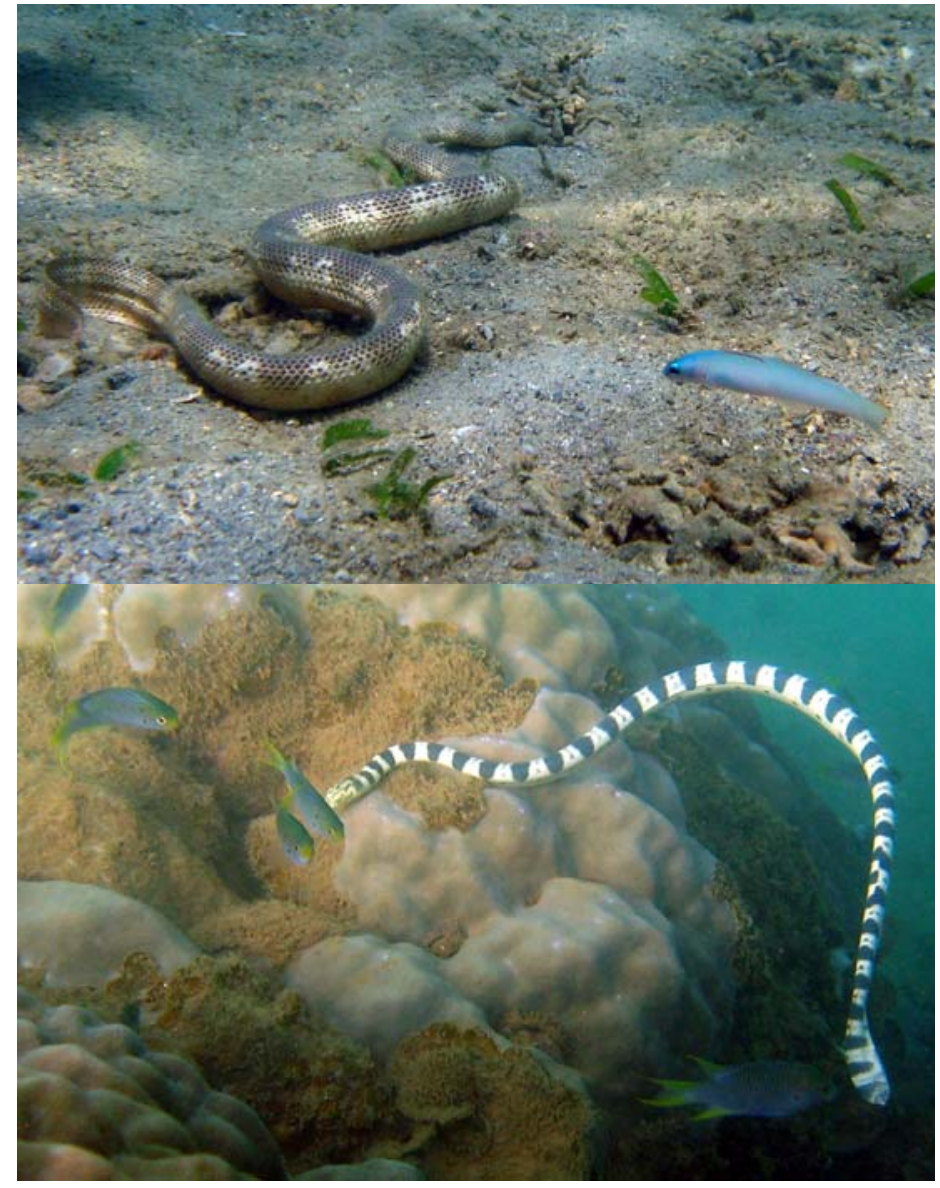

Fig. 1 a Horned sea snake (Acalyptophis peronii) in Baie des Citrons, Nouméa, ambushing a pale dartfish at the entrance of its burrow while a congener looks at. b Olive-headed sea snake (Hydrophis major) in Ouémo, Nouméa, hunting coral demoiselle
Few data are available on the in situ behaviour of sea snakes. Sea snakes are particularly abundant in the lagoon of New Caledonia (Ineich and Laboute 2002), including the reefs and shallow bays that fringe the city of Nouméa. Baie des Citrons, the most popular beach in the city, harbours a sizeable resident population of turtle-headed sea snake (Emydocephalus annulatus) which has been studied since 2002 (Shine et al. 2003; Shine 2005). Next in occurrence are the horned sea snake (Acalyptophis peronii; Fig. 1a) and the olive-headed sea snake (Hydrophis major; Fig. 1b). Other species

occasionally encountered in Baie des Citrons are the sea kraits Laticauda saintgironsi and L. laticaudata, Dubois' sea snake (Aipysurus duboisii) and Cogger's sea snake (H. coggeri). The relative abundance of both $H$. major and Acalyptophis peronii in Baie des Citrons makes this site favourable to their study in the wild.

Horned sea-snakes were frequently observed foraging in burrows occupied by gobies in the sand flat (2 to $9 \mathrm{~m}$ depth) adjacent to the reef of Baie des Citrons (Fig. 1a). Pale dartfish (Ptereleotris microlepis) have been identified as a regular prey of horned-headed sea snake (Ineich and Laboute 2002; Fig. 1a).

Very much less is known about the habitat and ecology of the olive-headed sea snake and little information is available on its diet (McCosker 1975; Ineich and Laboute 2002). Olive-headed sea snakes from ca. $40 \mathrm{~cm}$ to over $1.0 \mathrm{~m}$, single or in groups of up to 4 individuals, were observed swimming on the reef flat, along the reef front, or above the sandy bottom of Baie des Citrons. The reaction of reef fishes to approaching olive-headed sea snake was either to seek protection among the spines of Diadema setosum urchins (as did Apogonidae) or to escape upwards in the water column (Pomacentridae), or to swim away (Labridae and honeycomb cod, Epinephelus merra). The specific avoidance responses of reef fishes show they identify olive-headed sea snakes as a threat. In one instance (Fig. 1b), a ca. 50-cm long olive-headed sea snake was observed swimming and foraging along the fringing reef until it stopped 20-30 cm from a group of coral demoiselle (Neopomacentrus nemurus), retracted its neck to draw an 'S'-like posture and repeatedly, swiftly projected its head towards the nearest fish in the group. The snake harassed the fishes for about three minutes without success. The coral demoiselles managed to keep just distant enough to constantly stay out of its reach.

The importance of sea snakes as predators upon the fish community inhabiting the fringing reef remains to be quantified.

\section{References}

Ineich I, Laboute P (2002) Sea snakes of New Caledonia. IRD, Paris

Mc Cosker JE (1975) Feeding behaviour of Indo-Australian Hydrophiidae. In Dunson WA (ed.) The biology of sea snakes. University Park Press, Baltimore, pp. 217-232

Shine R (2005) All at sea: aquatic life modifies mate-recognition modalities in sea snakes (Emydocephalus annulatus, Hydrophiidae). Behav Ecol Sociobiol 57:591-598

Shine R, Shine T, Shine BG (2003) Intraspecific habitat partitioning by the sea snake Emydocephalus annulatus (Serpentes, Hydrophiidae): the effects of sex, body size, and color pattern. Biol J Linn Soc 80:1-10

\section{P. Borsa $(\bowtie)$}

Institut de recherche pour le développement, Nouméa, New Caledonia e-mail: borsa@noumea.ird.nc 